Article

\title{
The Early Literary Evolution of the Notorious Pirate Henry Avery
}

\section{Richard Frohock}

English Department, Oklahoma State University, Stillwater, OK 74078, USA; richard.frohock@okstate.edu

Received: 27 October 2019; Accepted: 22 December 2019; Published: 30 December 2019

\begin{abstract}
Henry Avery (alternately spelled Every) was one of the most notorious pirates of the late seventeenth and early eighteenth centuries, and scholars have written much about Avery in an effort to establish the historical details of his mutiny and acts of piracy. Other scholars have focused on the substantial literary production that his life occasioned; the early literary history of Avery's exploits evolves quickly away from the known facts of his life, offering instead a literary trajectory of accumulated tropes about Avery's motivations, actions, and transformations. This literary invention of Avery is a compelling subject in itself, particularly as writers used his story to explore pressing philosophical and political concerns of the period. In this essay, I consider how early fictions about Avery look well beyond the history of a particular pirate to ruminate on topical ideas about the state of nature, the origins of civil society, and human tendencies toward self-interest and corruption that seem-inevitably - to accompany power and threaten civil order, however newly formed or ostensibly principled.
\end{abstract}

Keywords: pirates; Avery; Atlantic World; eighteenth-century literature; state of nature; Thomas Hobbes

\section{Introduction}

Henry Avery (alternately spelled Every) was one of the most notorious pirates of the late seventeenth and early eighteenth centuries. A midshipman on a Caribbean expedition to salvage a wrecked Spanish treasure ship, Avery and his co-conspirators ousted their captain while anchored at Coruna, Spain, and set out to make their fortunes in the East and West Indies (Lincoln 2016, pp. 86-87; Cordingly 2004). The pirates' capture of a rich treasure vessel belonging to the Mughal Emperor in India caused disruption to England's trade, as the Mogul soon retaliated against the East Indian Company (Lincoln 2018, p. 98). Six members of Avery's crew were later caught and brought to trial, and the government took the unusual step of publishing the trial records to make a statement about the heinousness of piracy and Britain's determination to eradicate it (Burgess 2009). Avery himself disappeared in the West Indies and was never apprehended; although some have speculated that he eventually returned to Britain, his fate is unknown. (See Appendix A for an eighteenth-century engraving of Avery).

Some years after his voyage and the trial of some of his crew, Avery's exploits became the subject of numerous literary works, and his later life was variously invented in colorful fictions; he is arguably the most written about English pirate in an era when pirate narratives proliferated, making appearances in ballads, newspaper accounts, plays, short prose fictions, and novels over a period of about two decades. The authors of Avery narratives show little allegiance to actual persons and real events, although they often embrace the guise of presenting true histories. Instead, the literary history of Avery evolves quickly away from the known facts of his mutiny and piracy, offering a literary trajectory of accumulated tropes about Avery's motivations, actions, and transformations. This literary invention of Avery is a compelling subject in itself; on the model of Mikhail Bakhtin's polyglossy, 
each new literary instantiation incorporates, often references, and reacts to or contradicts previous ones (Voloshinov 1973).

While some scholars have worked to establish the historical details of Avery's mutiny and acts of piracy (Baer 1994; Lázaro 2011; Rennie 2013), others have focused on the substantial literary production that his life occasioned. The elusive Avery created abundant imaginative space for conceptualizing the meaning and implications of the pirate life, and Avery's large literary appeal is driven by the suitability of his story for exploring pressing philosophical and political concerns of the period. Baer (1995) has argued that the literature produced about Avery from 1709-1728 presents him as a working-class hero, as an example of protest lore; Dryden (2000) argues that Avery fictions are designed to appeal to tradespersons and represent the values and means by which a mercantile class can rise to power and wealth. Rennie (2013) examines Avery fictions in terms of the rise of the novel, its emphasis on realism, and its celebration of "the adventure of individualism," aiming to meet reader expectations in pursuit of commercial profit (p. 29). Lincoln (2018) notes that "pirate narratives were a versatile means of rehearsing the problems and issues of the age" and considers how various works about Avery provide information about the diverse audiences drawn to versions of his story (p. 104).

In this essay, I examine how early literary treatments use Avery's story as a platform for thinking through fundamentals of civil society. Avery's initial turn to crime can be imagined as move into a Hobbesean state of nature, and his creation of a rogue republic allows for consideration of the ways and means of exiting this disadvantageous state. What is more, Avery fictions examine the possibilities and challenges of managing civil order over time, considering in particular how a government ostensibly founded upon principles of equity may succumb to self-interest, corruption, and fraud. In this way, the story of Avery gives satirists matter for critiquing the human failures that repeatedly lead to political exploitations within mainstream and rogue communities. ${ }^{1}$

\section{Ballads}

The earliest literary portrait of Avery (of which I am aware) is in a ballad published under the title "A Copy of Verses Composed by Captain Henry Avery" (1694). ${ }^{2}$ Ostensibly the work of Avery himself, the ballad focuses on Avery's initial decision to turn to crime and irreversibly separate from civil society. Avery's ambition is first and foremost a materialist one, as he determines to "glut [his men] with Gold" ( Anonymous 1694, line 2); to accomplish his ends, he boldly declares that he has put himself in a state of perpetual war with the French, Spanish, Portuguese, and the "Heathen" ( Anonymous 1694, lines 7-8). Avery characterizes his relationship to England is more ambivalent terms, stating that he honors St. George, the patron Saint of England, but also makes it clear that he will not refrain from attacking ships of any nation, including England. His methods, too, entail extreme violence: those who do not request quarter in a timely manner will be slaughtered without mercy: "We save nothing living, alas 'tis too late" ( Anonymous 1694, line 46).

The ballad portrays Avery as one who breaks decisively with society and puts himself in an unending Hobbesian state of nature-a state of war-with the rest of mankind. This representation of Avery as a humani hostes generis, an enemy of mankind ready to commit inhuman brutalities in pursuit of his goals, is in keeping with the characterization of him presented by "The Proclamation for Apprehending Henry Avery" issued by the Scotland Privy Council (1696) and by the prosecution for

1 Some historians have argued that pirates created rogue communities founded in egalitarian principles to escape socio-economic oppression in mainstream society (Hill 1985; Rediker 2004); by contrast, Benton (2005) as argued that pirates worked to maintain lawful status and their connection to civil society. Literary depictions of Avery present a broad range of viewpoints, in many cases satirizing pirate motives and abilities to maintain an equitable republic. Baer (1980, p. viii) notes that pirates served as a vehicle for social satire, and he also discusses pirates as furnishing materials for serious considerations of the origins and nature of civil government, which are key ideas I elaborate in this essay.

2 (Lincoln 2016, pp. 86-87), states that the ballad may have been composed to incriminate Avery and defend the merchants backing the Corruna adventure. Other ballad variants followed, including one published in The Flying Post in 1696 (Baer 1995). 
the High Court of Admiralty, which prosecuted several of his crew for their "villainous robberies and barbarities" in 1696 (England and Wales High Court of Admirality 1696). The ballad, however, begins to transform the story of Avery's turn to piracy by omitting mention of the mutiny at Corunna and instead obliquely blaming England for unjustly dispossessing Avery of property he held in Plymouth and "Cat-down" (likely Cattledown), where he had intended to settle ( Anonymous 1694, lines 13-15). Avery's resentment at being unjustly treated by a "false-hearted" England provides incentive for his piratical turn (Anonymous 1694, line 50). This injustice has some parallel to the historical Avery, whose mutiny was triggered by the failure of the Spanish Treasure Company to pay the crew wages while they waited for weeks to depart for the West Indies. The details are thin, and the charges are not elaborated, but the ballad expands on the notion of Avery as a victim of fraud, not at the hands of a private company but rather of England generally.

\section{3. "Some Memoirs" (1708)}

When "Some Memoirs Concerning that Famous Pyrate Capt. Avery" appeared in 1708, it picked up where the 1694 ballad left off by building on the ideas it had introduced over a decade before. ${ }^{3}$ The anonymous author of the "Memoirs" references the ballad when they mention having read verses written by the pirate poet Avery himself that "made mention of some Injuries the Captain had received, and that he was resolved to quit this side of the World, where nothing was to be met with but Frauds and Injustices" ( Anonymous 1708, p. 346). The "Memoirs" not only repeats the claim that a young Avery had been defrauded of his property but also expands on the idea by creating a backstory for Avery's father, depicting him as a successful mariner who acquired enough wealth to purchase an estate near Plymouth, which he intended for his son's inheritance. After his father's death, Avery builds a house on the property with the proceeds of his own earnings, but before he can take up residence, he discovers that he has been served with "Declarations in Ejectment." After being taken to trial and stripped of all his possessions, an enraged Avery publicly accuses "both Judge and Jury, and laid Partiality and Bribery to their Charge" ( Anonymous 1708, p. 347). Whereas the ballad represents Avery as still identifying with England in his self-imposed exile, the "Memoirs" take matters a step further, stating that Avery's resentment at his unjust treatment leads him to a general condemnation of his countrymen: "he conceived a mortal hatred against the whole Nation, for the suppos'd injury of a few Persons" ( Anonymous 1708, p. 348).

Avery resolves to exact revenge by getting command of a merchant vessel and convincing his fellow mariners to turn pirates with him. Private injuries motivate Avery, but he persuades his accomplices to join him by broadly condemning the injustices they suffer in traditional mariner professions. He tells them they have no reason to remain loyal to merchants who "permitted the bravest Fellows to grow old, lame and miserable in their Service, without having any regard to their Labours." He furthermore tells them that the navy offers no more assurance of rewards commensurate with their labor: "'twas an equal frenzy to hazard all for the Government, where Preferment seldom attended true Merit" ( Anonymous 1708, p. 349). He tempts them further by appealing to their material desires; evoking a fantasy of conquest that draws on the legends of Spanish empire, Avery claims that the men who join him will be spectacularly rewarded for their efforts: "one days resolute Fight should make the Residue of their Lives a scene of pleasure," as their expeditions will "meet with Worlds Richer than the Mines of Potosi" (Anonymous 1708, p. 349). The men are convinced by these twin arguments, and they sail for Jamaica and then the Indian Ocean, where they attack the Mughal's ship the Ganj-i-Sawai (sometimes refered to as the Gunsway in Avery narratives). Like the ballad, the "Memoirs" omits the story of the mutiny at Corunna and instead perpetuates and enlarges on the trope of a world that is corrupted and

3 The revival of Avery literature during the first decade of the eighteenth century may have been due to the conflation of his story with the pirates inhabiting Madagascar at the time, and the schemes for eliminating their presence there (Lincoln 2018, p. 99; Bialuschewski 2007). 
exploitive in its legal, merchant, and military institutions. The men who mutinied at Corunna were disgruntled over unpaid wages; the "Memoirs" extends the argument by depicting ordinary mariners are powerless against systemic fraud and corruption within their traditional professions. By contrast, if they seize control over their own circumstances and destinies, the "Memoirs" promises, they will become phenomenally wealthy with virtually no labor.

The "Memoirs" also appears to be one of the earliest (if not the first) account to introduce the notion that Avery and his accomplices organized a successful pirate republic in Madagascar. ${ }^{4}$ Revenge crime may be the short-term response to victimization, but the "Memoirs" depicts the pirates' long-term fix as the creation of an alternative and more equitable social body which they govern with self-made laws. In keeping with earlier tropes of pirate loyalty and regulation within their communities, a trope found in Alexandre Exquemelin's Buccaneers of America (1678) for instance (Exquemelin 1969, pp. 71-72; Frohock 2012, pp. 35-36), the "Memoirs" describe Avery as very conscientiously distributing plunder in equitable dividends, "according to the Law of Pyrates, who tho' they make it their Business to prey on Persons of a different Life and Conversation, yet amongst themselves observe the severest Rules of Justice" ( Anonymous 1708, p. 350). ${ }^{5}$ After amassing considerable wealth from their plundering voyages, Avery and his fellows settle on Madagascar and build a fort to protect their newly formed society. They also create a legal code because they realize that "Bulwarks and Artillery only were not able to preserve this Pyratical Government; several new Laws and Customs were proposed and consented to by the generality of these Sea Rovers, conducive as they imagined, to the welfare of their new State" ( Anonymous 1708, pp. 351-52). The pirates grant Avery the power of a Duke, and he presides over the government they form. The pirate republic becomes a safe harbor for other pirates, who pay for this protection, and Avery continues to amass wealth, although he no longer ventures himself. The narrator does not go into detail about the terms of the pirates' social organization, but he does suggest that the pirate republic runs very smoothly and with considerable contentment. The narrator reports that Avery is rumored to have attempted to purchase his pardon in order to return to England but casts doubt on the claim by remarking that Avery would have little incentive to leave command of his "Petty Kingdom" which furnishes him with a very comfortable, even utopian existence (Anonymous 1708, p. 353).

Building on sparse but suggestive details in the ballad, the "Memoirs" reimagines Avery more fully as a victim of exploitation at the hands of a society that is corrupted in its economic, military, and legal systems. Those corrupted institutions, which carefully guard powerful persons from culpability as they enact injustices, cause Avery and the other men to turn to crime for personal revenge and for the restitution of wealth wrongfully taken or withheld from them. Additionally, the "Memoirs" extends the Avery legend by drawing on pirate lore generally to imagine him as a capable ruler over a rogue society that at least internally operates according to equitable laws and customs (although it clearly enriches itself at the expense of people of other countries). In these ways, the "Memoirs" transforms narrative elements obliquely hinted at in the ballad into a fuller study in the corruptions of the mainstream world and alternative constructions of civil government.

\section{The Life and Adventures of Avery (1709)}

The Life of Avery (1709) was the next major publication to build on the narrative tropes it inherited and imaginatively enlarge the details and implications of the notorious pirate's history. The Life purports to be "faithfully extracted from [the] Journal" of Adrian Van Broeck, a person who claims to have been captured by Avery and who agreed to join the pirates only as a survival strategy until he could affect an escape (Broeck 1709, title page). The Life does with the "Memoirs" what the "Memoirs"

4 For historical information about the pirates who ended up on Madagascar, see Baer (2001).

5 In sharp contrast to their internal practice of equity, the "Memoirs" also gives a glimpse into the Pirates' harsh treatment of captives, particularly women, and natives of Africa. 
did with the ballad: it takes cues from its literary predecessors and amplifies and transforms its sources. In particular, The Life repeats and elaborates on the circumstances of Avery's disgruntled relationship with England, filling in Avery's childhood background and making clear that he is driven to crime by the experience of being repeatedly victimized. The Life makes the betrayal of Avery more intimate and personal by claiming that it was Mr. Knowles, an unscrupulous guardian, who steals Avery's inheritance and family estate while he is at sea (Broeck 1709, pp. 7-9). As in the "Memoirs," The Life echoes the claim that the legal system proves ineffective in protecting or restoring Avery's rights because of a treacherous lawyer who proves adept at concealing the crime (Broeck 1709, p. 9). The Life adds another intimate layer of betrayal by reporting that Avery also found himself cheated in romance when he is coaxed into marrying a woman who proves to be already pregnant with another man's child (Broeck 1709, p. 21). In his early years, Avery learns the way of the world, which is corruptly self-serving. Abused by those who should nurture and protect him, and exploited in family, finance, law, and love, young Avery turns to a life of piracy.

To emphasize that circumstances drive Avery to a life of crime, the narrative repeatedly makes references to Avery's virtues and potential. He is a well-intentioned man and a hardworking, proficient sailor, and on a later voyage to the West Indies, when he commands a merchant ship, Avery becomes known for his fairness, prudence, and justice. The narrator states that Avery proves adept at "gaining the Affections of the Mariners" and concludes that that had he used his "Vertues, both natural and acquir'd," for the good of the nation, he could have achieved as much as the seadogs Drake and Hawkins (Broeck 1709, pp. 18, 19). His betrayal in financial, familial, and judicial realms instead propel him to apply his considerable abilities to a path of crime.

Like the "Memoirs," The Life thematizes the exploitation of mariners generally. Avery persuades men to join him in his piratical purposes by reminding them of the unfair circumstances of their employment, emphasizing the lack of recompense from Merchants "who suffer'd the bravest Fellows to grow old, lame, and miserable in their Service, without having any Regard to their Labours"; and from the government, "where the Tarpawlins of Honour had nothing to expect for the Reward of their Wounds and Bravery but a poor Apartment in an unprovided Hospital" (Broeck 1709, pp. 25-26). By contrast, Avery promises the men enormous wealth, here again evoking the mines of Potosi to symbolize the riches that await (Broeck 1709, p. 26). The Life also is consistent with the Memoirs in reporting that Avery makes the men's lives more equitable under his rule, following the "Law of Pirates," which stipulates that plunder be divided evenly according to equitable shares (Broeck 1709, p. 39). When the men decide to leave off cruising and establish a colony on the island of Madagascar, they democratically formalize their government: "several new Customs and Ordinances were propos'd, and consented to by the Generality of the Rovers, conducive as they imagin'd necessary for the Preservation of their new State" (Broeck 1709, p. 43). The men give everyone the power to stay or leave, and they appoint Avery to rule over their "Republick of Pirates" (Broeck 1709, p. 43). Over time, Avery fortifies their community and expands his power and his territories, making local princes into his tributaries (Broeck 1709, p. 46).

Avery initially seems to rule in a way that fulfills the promise of the pirates' republican principles, but this is where The Life departs significantly from the "Memoirs" and forges a new narrative trajectory. Rather than positing the creation of a rogue utopia, The Life interrogates the idea of the well-governed pirate republic, indicating that their society on Madagascar does not remain untroubled for long. The narrator notes that the stability of the pirate government, like all civil governments, is threatened fundamentally by familiar human passions and desires which inevitably arise: "in all Constitutions and Bodies Politick, there are still some Members that compose it, of different Inclinations, and who, sway'd by Ambition, or byass'd by Disaffection, think themselves capable of commanding the whole, and highly injur'd while they are made subservient to a Power that is superior to 'em" (Broeck 1709, p. 47). In The Life, this role is supplied by a new character, de Sale, a captured Frenchman who joins Avery and advances to position of viceroy, second in command in the republic. The Mughal's granddaughter, whom Avery has captured and made his (willing) bride, is at the center of the tale 
of corruption. De Sale wants Avery's wife for himself, and he organizes a coup to accomplish his desire, convincing his fellow Frenchman that Avery has despotic intentions and that they can only preserve their liberty through his overthrow (Broeck 1709, pp. 49-51). The coup attempt fails, however, when the plot is revealed to Avery, and Avery's supporters are able to capture the rebels, including the treacherous de Sale.

The failed coup transforms the pirate society fundamentally. The execution of the rebels is by impalement, an especially brutal method that successfully demonstrates the violent capacity of the state and makes its victims "the Objects of other Folks Terror" (Broeck 1709, p. 54). The extreme violence of the punishment for treason is directed not only—or even primarily-at the criminals, but at citizens generally, who see the vast imbalance of power between state and citizen dramatized in the execution. After brutally defeating the traitors, Avery's power is confirmed and enlarged: "the great Council of the Island agreed, one and all, to pass such wholesome Acts in his Favour, as rais'd him to a Pitch of Sovereignty not any ways inferior to the Greatest Potentates. 'Twas not only made high Treason to contrive against his Person, but to speak little of his Authority; and he saw himself invested with a Power as despotick as one of the most arbitrary Principles could wish for, or the highest Ambition could have in View" (Broeck 1709, p. 54). Avery proceeds to exert his new powers later in the narrative by violently conquering the natives of Madagascar with whom he had previously formed a treaty (Broeck 1709, p. 58). The private passions of de Sale, once exposed, serve as a catalyst to transform the young republic into an autocracy.

For the author of The Life, the story of a flourishing pirate republic was less compelling than a story of corrupt human nature marring civil society. Its author posits that in any society, whether mainstream European or a rogue state, individuals will contrive to violate laws and the rights of their fellows in order to gratify private passions. Governments "that are funded upon Violence and Rapine," are particularly insecure, the narrator concludes (Broeck 1709, p. 58). In this case of the pirate republic, Avery responds to the coup attempt by promoting a culture of fear through the commission of state-sanctioned violence, and he leverages the failed plot to strip the populace of civil rights and solidify authoritarian power. A Hobbesian philosophy of human nature prevails, and what the pirates finally establish is a Leviathan in which the monarch overawes all into submission. The pirate republic is a short-lived experiment that eventually collapses into a familiar form of tyranny.

Given the similarities between the pirate and mainstream worlds, it is perhaps not surprising that Avery at the close of the narrative expresses his desire to blend back into English society by purchasing a pardon. This is in direct contrast to the ending of the "Memoirs," which suggests that Avery had no compelling reason to want to return to England, since he created a utopia in Madagascar. The Avery of the Life finds that he is subject to the same hostility-the same attempts to strip him of his wealth and family happiness-in the world he has created, however. Finding no advantage, no substantially different culture or way of being in the Madagascar pirate republic, the pirate Avery, who also expresses some awareness of guilt for his actions, longs, finally, to return (Broeck 1709, p. 55).

Although Avery's request for pardon is not fulfilled, the narrator expresses the compatibility of mainstream and pirate worlds in one final way. The pirate Avery wants to blend back into mainstream life, and the pirate world also seems suitable for incorporation in the expanding British empire. The narrative finishes with a brief description of Madagascar as a fruitful island that supports numerous trade commodities, including rice, copper, and wood, recommending it as a site of British colonization for its commercial and its military value (Broeck 1709, pp. 63-64). This could be achieved, he suggests, either by conquering or pardoning the pirates. The narrative ends, then, with the possibility of reintegrating mainstream and rogue society. Indeed, the two worlds seem not that far removed in their political and social make-up. The pirates live outside the law of nations, and must be replaced with official colonial agents; however, the pirates can be absorbed into empire-they are not so criminalized, and mainstream society is not so virtuous, that they cannot, in this instance, be recuperated. In a sense, piracy functions as an emblem for British colonization-the unjust usurpation of goods, 
property, and political authority is eventually rationalized, sanctioned, and absorbed into mainstream empire and law. ${ }^{6}$

\section{The Successful Pyrate (1713)}

A few years after the publication of The Life, Charles Johnson brought Avery to the stage in The Successful Pyrate, performed in Drury Lane's Theatre Royal in 1712 (Dryden 2006). This play continues the literary evolution of Avery by referencing key ideas introduced in earlier Avery narratives and further developing them. The play focuses on the Madagascan pirate republic and Arviragus's (Avery's name in the play) period of rule there, and it elaborates in particular on the problem of private desire disrupting the principles of equitable social organization the pirates have allegedly embraced. ${ }^{7}$

The Successful Pyrate opens with a scene that dramatizes the discontent that is brewing in the pirate republic. It features a disagreement between Piraquo and Boreal, a critic and a supporter of Arviragus, respectively. Boreal portrays Arviragus as courageous, bold, and admirably ambitious, and he tells the now familiar story of Arviragus turning to a life of crime only after being betrayed by his country and his closest associates. After serving in the navy, Arviragus returns to England to discover that not only will he not be rewarded for his service but also that his friend Malvoli (instead of his guardian Mr. Knowles, as reported in The Life) has cheated him of his estate and his love interest. Piraquo, by contrast, describes Arviragus as an "overgrown Thief" and asks Boreal if in supporting Arviragus' rise to power by criminal means he is not endorsing a Hobbesean view that "all have a right to demand all ... in the simple State of Nature" (Johnson 1713). ${ }^{8}$ Boreal replies by insisting that all great founders of nations, like Romulus, use the same means to ascend to power and insists that Arviragus deserves praise for uniting "a Race of Vagabonds" under civil order. In this opening scene, the play explores the paradox of the "Royal Out-law," using the figure of the pirate-king to examine the origins of social order and the just exercise of power (Johnson 1713, p. 3). It draws on previous literature by putting two views of Avery into immediate, direct dialogue, and it primes viewers to have these two opposing viewpoints in mind as the action unfolds, setting up the question as to which will prevail in understanding Arviragus and his rogue nation.

The Successful Pyrate also expands the story, introduced in The Life, of De Sale's attempted rebellion against Avery. As in The Life, De Sale's motives are those of self-advancement; as second in command, he envies Arviragus both for his position of power and his claim to Zaida, the name Johnson gives to the captive Mughal's granddaughter. In the Life, De Sale draws on national conflicts by convincing the French to support him in overthrowing the English pirate Avery. In Johnson's play, De Sale easily finds fellow rebels within the pirate community without invoking nationalist divides. De Sale reveals that he has persuaded Piraquo to be his agent, and Piraquo has in turn incited the mob with "monstrous lies" about Avery's conduct (Johnson 1713, p. 26). De Sale rebels from a position of power, employing false rhetoric as a means to assemble support among the common class, who prove all too easily swayed by his falsehoods.

Johnson's play satirizes the rebels from the common class of pirates as buffoonish, incompetent, and more concerned with the pleasures of drinking than with political reform. They show no competence when it comes to political leadership, and the idea that these common pirates could create an equitable alternate civil order comes across as ridiculous. Rather, these mariners become tools of ambitious men who use them to leverage their own power and desire. When Arviragus's supporters discover the plot, they in turn easily manipulate the would-be rebels, who happily abandon their insurrection when offered a full pardon. Tulip, a prominent agitator who has schemed with

6 Various scholars have examined piracy as interconnected with the expansion of British empire; for example, see Latimer (2009) and Hanna (2015). Whereas I read the description of Madagascar as sincere colonial advocacy, Jones (2012) reads the description as mocking in tone.

7 Dryden (2000) reads this play as a satire aimed at critiquing English society and government (pp. 72-84).

8 References are two the second edition of the play; I have been unable to locate a copy of the first edition. 
De Sale, also shows a lack of authentic commitment to the cause: like the members of the mob who readily accept personal pardons in exchange for giving up the rebellion, Tulip quickly turns on his co-conspirators when he sees an opportunity to advantageously situate himself. Believing he plays both sides, he boasts, "I, like a deep Politician, secur'd my self both Ways" (Johnson 1713, p. 44). Through the changeability of these characters, The Successful Pyrate expands the story of De Sale's rebellion to illustrate the widespread presence of corruption in the pirate kingdom. Pirate leaders and the common class alike act to secure self-interest over public welfare. The rhetoric of an alternative social structure with more liberty and equality is undermined in each of the play's acts, by characters in various social positions.

This play also examines in detail the question of Arviragus's fairness as a ruler. When Arviragus makes his first appearance on the stage, he has just captured the Mughal's ship, loaded with "Women and Gold," which Arviragus is viewing and preparing to divide. Arviragus makes a point to display his egalitarian principles, telling De Sale to divide the sailor's shares "without Delay or Fee"; he goes so far as to say he would kill De Sale should he try to cheat anyone of even "a Doit" (Johnson 1713, p. 8). He then takes a moment to pontificate on the origin of his power, freely bestowed on him by his men with "Universal Voice," and he applies the same high standards to himself that he sets for De Sale, declaring that should his regime ever become corrupted, "may I [then] fall,/Like some o'erweening Tyrant, who believes Himself a Law, and Governs by his Lust" (Johnson 1713, p. 9). Further evidence of his egalitarian principles becomes evident in his interactions with his new (male) captives. Aranes, an omrah and one of the captive men, questions Arviragus's integrity, calling him a "haughty Pyrate"; in response, Arviragus declares that he uses "Power with Mercy," and that he does not enslave those he captures, allowing Aranes free choice to join their society or return to his own. (Notably, Arviragus does not extend the same freedom of self-determination to his female captives. They, like gold and jewels, are counted among the plunder (Johnson 1713, pp. 9-10)). ${ }^{9}$

In spite of Arviragus's high-minded declarations, there are early indications that he will not be able to live up to his own standards. Part of the men's complaint is that while Arviragus choses a wife from among the captive women, the rest are distributed by lottery. Piracquo declares this "an Imposition upon the free Subject," and although Piracquo is out to undermine Arviragus, he has a point in that Arviragus seems blind to the inequity he creates by claiming a privilege and the power of choice for himself that he denies to his men and to the captive women, who are treated as commodities with no power of self-determination (Johnson 1713, p. 14).

A fuller test of his principles also centers on Zaida, the captive who is his love interest. When Arviragus catches Zaida with Aranes and recognizes their love for one another, he has to struggle with his anger as he asserts his right to Zaida. Aranes calls Arviragus a devil, "bloody Pyrate," and a "Tyrant," but Arviragus maintains that he rules by civil law. He argues that powerful conquest is a preliminary to establishing a republic: "I gave 'em Laws, and dropt the Conqueror's Sword/To rule by Civil Right" (Johnson 1713, pp. 22-23). Arviragus struggles with his private desire in this instance, however, and he separates the two lovers so he can attempt to win over Zaida unopposed. When he later finds them together (a scene set up by De Sale to enflame his anger), Arviragus, faced with their defiance, orders Aranes to be killed. His desires overcome his reason and his sense of justice; set up by De Sale, he fails the test, as De Sale predicts, and he betrays the principles of liberty and equity he espoused in the play's opening scene. As Zaida charges, the "Gloss of Virtue" comes off when he is denied his unjust wishes (Johnson 1713, p. 33). In this dramatic rendering, the story of the pirate who turns away from society to build his own on more virtuous footing is shown to be subject to familiar corruptions, as Arviragus exploits his power for the fulfillment of personal desire.

There is yet another way in which the civil society Arviragus has built is exposed as corrupted and systemically flawed: the trial of the would-be rebels, led by De Sale, is run in a buffoonish fashion,

9 (Lincoln 2016, pp. 192-96), provides a study of Avery stories and their focus on the treatment of female captives. 
and it is clear that the council for the defendant and the judge are less interested in fair deliberation than they are in finishing in time for their lunches. The prosecution and the defense exchange statements that are full of Latin jargon, and the judge declares that he is willing to go through the formalities of the proceeding but that "I am resolv'd before-hand to hang 'em all" (Johnson 1713, p. 54). De Sale is certainly guilty of treason, having attempted a coup for his own empowerment, but he nonetheless has a valid point when he declares the proceedings a sham after his conviction: "Ye empty Tools of Arbitrary Power,/Why do you use these silly Forms of Justice?" (Johnson 1713, p. 55). Although the verdict is a fair one, the trial has been theater rather than a real deliberation of facts. Under the leadership of Arviragus, the legal system is reduced to an instrument of power, run by those who are minions of the king.

In an unexpected turn at odds with the play's opening scene and the Avery literary tradition generally, Johnson concludes The Successful Pyrate with a jingoistic panegyric on Britain as the only sovereign state where true justice reigns. Arviragus reveals that he was tempted to return privately to Britain and bribe his way to a pardon, but Boreal, in a new take on this familiar plot element, declares that justice cannot be corrupted in Britain. Arviragus agrees, declaring that in Britain, the "Goddess Themis rules in Person,/She holds the equal Balance of the Globe,/And trembling Guilt dares not approach her Throne" (Johnson 1713, p. 62). This high praise for Britain punctuates the failures of the pirate republic on display throughout the play. From the highest to the lowest, self-interest undermines equity in the civil society created by the pirates. The common pirates, concerned only with their own social positioning and physical comforts, govern incompetently and are easily led to embrace injustice. The leaders among the pirates competently articulate a republic grounded in equitable principles, yet they prove to be subject to the same corruptions they experienced and renounced before turning to piracy. Arviragus' friend Malvoli cheated Arviragus of his mistress in England, but Arviragus similarly uses his power to attempt to supplant Aranes and impose himself on Zaida. Meanwhile, one of his closest associates, De Sale, plots to strip him of his power, wealth, and his love interest in turn. The pirates take the worst elements of the society they have left and replicate them in their own.

In the final act, even Arviragus recognizes his failure to lead by his declared principles. He repents of his abuse of power and his attempted murder of Aranes and is authentically horrified at what he has become: a leader who abuses his authority for private purposes. When he discovers that Aranes is alive-and, conveniently, that Aranes is his son-he gives up his pursuit of Zaida and hands over his kingdom to Aranes. By deposing himself, he makes good on his pronouncement in the first act that his reign should end if should he ever stray from his guiding principles. His moment of clarity does not alter the play's exposure of the widespread failure of the pirates generally to live by their principles, however. Because of the universality of human vice, the pirates fail to create a truly revolutionary new civil society; rather, their experiment ends by confirming the old order from which they have departed as the best possible one. Britain remains the exemplum of fair governance: as Boreal proclaims, "in Britannia Strict Justice Sways alone" (Johnson 1713, p. 62).

\section{Conclusions}

While there is much shifting in terms of the claims about the particulars of Avery's life, the earliest Avery fictions build one off the other, pursuing an expanding range of topics and perspectives. The story of Avery becomes a popular vehicle for philosophical considerations, particularly of the motivations behind a turn to crime and the possibilities of building and maintaining of a rogue society. Early literary treatments embrace the idea that mariners might turn to piracy because of abuses they experience within the sanctioned structures of mainstream society. This may have been the case with the historical Avery, but the literary treatments expand the theme beyond historical restrictions, beginning with the ballad of 1694, which initiates the idea that an injustice motivates Avery's turn to crime. The story quickly expands, with the "Memoirs" imagining specifics of Avery's victimization and, critically, adding the story of his founding of a pirate republic on the island of Madagascar. Subsequent Avery narratives soon subject this notion of a rogue king ruling over a civil paradise on a remote island to 
critical interrogation. The Life of Avery tells the story of an attempted duplication of the crimes Avery experienced within Britain - the stripping of his wealth, power, and romantic attachment-now within the pirate republic itself. This new narrative about corruption marring the pirate utopia is a key feature of Avery fictions that follow. The Successful Pirate extends this story, showing widespread vice that goes far beyond one resentful individual, indicating instead that virtually all of the pirates are willing to conspire, one against the other, for their own advantage. Even the pirate king fails to live up to his lofty oratory and succumbs to the temptation of wielding his power for private gratification.

The Successful Pirate makes a suitable ending point for this discussion of early Avery narratives, because it brings matters full circle in its final scene by celebrating Britain as the premier exemplar of a nation that in principle and practice follows the strict administration of justice. The rogue state of the pirates, full of corruption and perverted justice, serves as a foil for celebrating the British system of government, thereby inverting the idea that pirates could create new civil societies grounded in progressive liberties. The moment is a fleeting one in the literary history of the Avery story, however, because subsequent fictions return quickly to the idea that there are substantial continuities between the mainstream and rogue worlds, based on the seeming ubiquity of the egoistic pursuit of self-serving advantage. The theme is one that continues in later Avery fictions such as The King of the Pirates (Avery 1719) and the account of Avery in the General History of the Pirates (1724), both of which follow The Successful Pyrate in incorporating the idea that a pirate republic would soon replicate the corruptions of civil society in Europe, and, more particularly, Britain. ${ }^{10}$ By emphasizing parallels between pirate life and mainstream society, rather than the rupture that the piratical turn causes, these writers explore human tendencies toward self-interest and corruption that seem inevitably to accompany social power, however newly formed or ostensibly principled.

As this brief survey of the earliest Avery fictions indicates, through the imaginings of Avery's biographers, the mutiny and piracy of a small group of men became the basis for broad philosophical and literary conversation. The shifting representations, though often represented as true histories (each correcting the mistakes of the last), are really not intended to be revisions of Avery's true story, but rather revisions or re-articulations of topical ideas about criminality, human nature, and the fundamentals of civil society.

Funding: I thank the English Department at Oklahoma State University for providing travel funds so that I could present portions of this essay at academic conferences while the essay was in progress.

Acknowledgments: Thanks to the anonymous peer reviewers, and to Bo Frohock, for comments and feedback on draft versions of the essay.

Conflicts of Interest: The author declared no conflict of interest.

10 See Frohock (2015, pp. 470-71), for discussion of the Avery biography in the General History (Johnson 1724). The apparently fictional story of Captain Misson, which appears in the second volume of the General History, also contains elements that seem inspired by Avery tales (Frohock 2015, pp. 475-76). For a time, The King of Pirates was generally attributed to Daniel Defoe; Richetti (1975) discusses the work in terms of Defoe's development as a novelist, for example. Furbank and Owens (1994) disputed that attribution. Novak (2017) takes up the issue again, concluding that Defoe was likely the author. Ward (1710) offers another fictionalization of Avery's time in Madagascar, depicting the unhappiness Avery and his bride experience from knowing they can never return to their respective homelands. 


\section{Appendix A. Image of Avery}

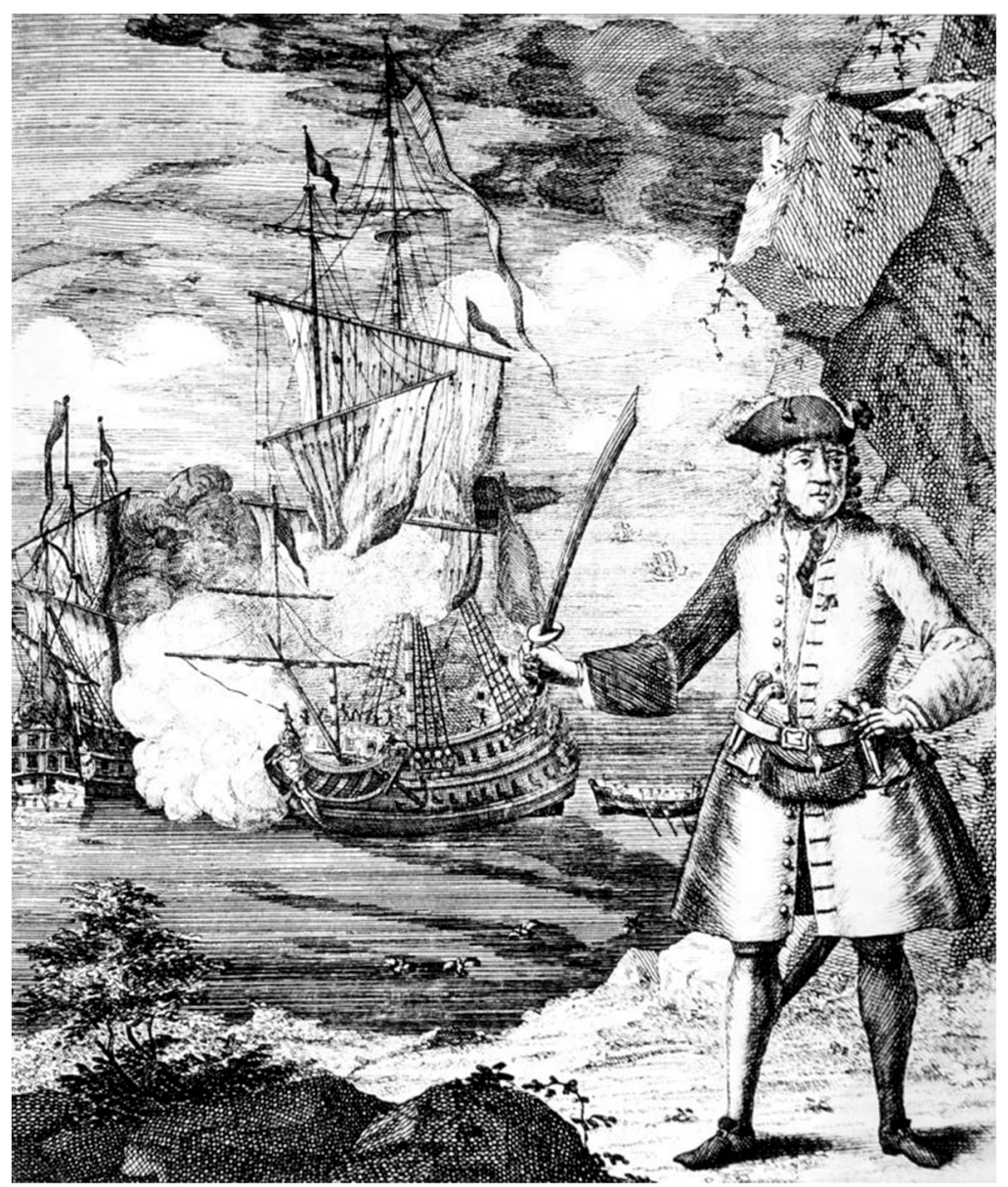

Figure A1. An eighteenth-century engraving of Captain Avery. This image is taken from WikiMedia Commons (a database of public domain material). PortCities.org.uk identifies the artist as W. Tett and the engraver as W. Pritchard with date unknown. The original is credited to The National Maritime Museum, Greenwich, UK.

\section{References}

Anonymous. 1694. A Copy of Verses Composed by Captain Henry Avery. London: printed for Theophilus Lewis.

Anonymous. 1708. Some Memoirs Concerning that Famous Pyrate Capt. Avery. In Monthly Miscellany; or, Memoirs for the Curious. London: printed by J. Morphew, pp. 344-53.

Avery, John (pseudonym). 1719. The King of Pirates: Being an Account of the Famous Enterprises of Captain Avery, the Mock King of Madagascar. With His Rambles and Piracies; Wherein All the Sham Accounts Formerly Publish'd of Him, Are Detected. In Two Letters from Himself; One during His Stay at Madagascar, and One since His Escape from Thence. London: printed for A. Bettesworth.

Baer, Joel H. 1980. Introduction. In The Life and Adventures of Captain John Avery (1709?) and The Successful Pyrate, Charles Johnson (1713). Numbers 203-204. Los Angeles: Augustan Reprint Society, William Andrews Clark Memorial Library, pp. iii-xiv.

Baer, Joel H. 1994. Captain John Avery and the Anatomy of a Mutiny. Eighteenth-Century Life 18: 1-26.

Baer, Joel H. 1995. Bold Captain Avery in the Privy Council: Early Variants of a Broadside Ballad from the Pepys Collection. Folk Music Journal 7: 4-26.

Baer, Joel H. 2001. Penelope Aubin and the Pirates of Madagascar: Biographical Notes and Documents. Eighteenth-Century Women: Studies in their Lives, Work, and Culture 1: 49-62. 
Benton, Lauren. 2005. Legal Spaces of Empire: Piracy and the Origins of Ocean Regionalism. Comparative Studies in Society and History 47: 700-24. [CrossRef]

Bialuschewski, Arne. 2007. Thomas Bowrey's Madagascar Manuscript of 1708. History in Africa 34: 31-42. [CrossRef]

Broeck, Adrian Van (pseudonym). 1709. The Life and Adventures of Capt. John Avery, the Famous English Pirate, (Rais'd from a Cabbin-Boy, to a King) now in Possession of Madagascar. London: printed for J. Baker.

Burgess, Douglas R., Jr. 2009. Piracy in the Public Sphere: The Henry Every Trials and the Battle for Meaning in Seventeenth-Century Print Culture. The Journal of British Studies 48: 887-913. [CrossRef]

Cordingly, David. 2004. Avery, Henry [known as Captain John Avery] (bap. 1659, D. 1696?), Pirate. In Oxford Dictionary of National Biography. Oxford: Oxford University Press, Available online: https://doi-org.argo. library.okstate.edu/10.1093/ref:odnb/924 (accessed on 6 June 2019).

Dryden, Robert Gordon. 2000. Successful Pirates and Capitalist Fantasies: Charting Fictional Representations of Eighteenth and Early Nineteenth-Century English Fortune Hunters. Ph.D. dissertation, Louisiana State University and Agricultural \& Mechanical College, Baton Rouge, LA, USA. Available online: http: //digital.commons.lsu.edu/gradschool_disstheses/7191 (accessed on 25 November 2019).

Dryden, Robert. 2006. The Successful Pyrate. A Play. As it is acted at the Theatre-Royal in Drury-Lane. In The Literary Encyclopedia. London: The Literary Dictionary Company Limited, Available online: https: //www.litencyc.com/php/sworks.php?rec=true\&UID=19498 (accessed on 7 October 2019).

England and Wales High Court of Admirality. 1696. The Tryals of Joseph Dawson, Edward Forseith, William May, [brace] William Bishop, James Lewis, and John Sparkes for several piracies and robberies by them committed in the company of Every the grand pirate, near the coasts of the East-Indies, and several other places on the seas: giving an account of their villainous robberies and barbarities: at the Admiralty sessions, begun at the Old-Baily on the 29th of October, 1696, and ended on the 6th of November. London: printed by John Everingham.

Exquemelin, Alexandre O. 1969. The Buccaneers of America. Edited by Jack Beeching. Translated by Alexis Brown. Mineola: Dover Press. First published 1678.

Frohock, Richard. 2012. Buccaneers and Privateers: The Story of the English Sea Rover, 1675-1725. Newark: University of Delaware Press.

Frohock, Richard. 2015. Satire and Civil Governance in A General History of the Pyrates (1724, 1726). The Eighteenth Century 56: 467-83. [CrossRef]

Furbank, Philip Nicholas, and William Robert Owens. 1994. Defoe De-Attributions: A Critique of J. R. Moore's Checklist. London: Hambledon Press.

Hanna, Mark G. 2015. Pirate Nests and the Rise of the British Empire, 1570-1740. Chapel Hill: The University of North Carolina Press.

Hill, Christopher. 1985. Radical Pirates? In The Collected Essays of Christopher Hill. Amherst: University of Massachusetts Press, pp. 161-87.

Johnson, Charles. 1713. The Successful Pyrate, 2nd ed. London: printed for Bernard Lintott.

Johnson, Charles. 1724. A General History of the Robberies and Murders of the Most Notorious Pyrates. London: printed for T. Warner.

Jones, Stephanie. 2012. Literature, Geography, Law. The Life and Adventures of Capt. John Avery (circa 1709). Cultural Geographies 19: 71-86. [CrossRef]

Latimer, Jon. 2009. Buccaneers of the Caribbean: How Piracy Forged an Empire. Cambridge: Harvard University Press. Lázaro, Fabio López. 2011. Predation's Place within Profit: Pirates and Capitalists within the Seventeenth-Century Rise of Lockean Liberalism. International Journal of Maritime History 23: 241-76. [CrossRef]

Lincoln, Margarette. 2016. British Pirates and Society, 1680-1730. London: Routledge. [CrossRef]

Lincoln, Margarette. 2018. Henry Every and the Creation of the Pirate Myth in Early Modern Britain. In The Golden Age of Piracy: The Rise, Fall, and Enduring Popularity of Pirates. Edited by David Head. Athens: The University of Georgia Press, pp. 97-105.

Novak, Maximillian. 2017. Did Defoe Write the King of Pirates? Philological Quarterly 96: 475-88.

Rediker, Marcus. 2004. Villains of All Nations: Atlantic Pirates in the Golden Age. Boston: Beacon Press.

Rennie, Neil. 2013. Every and All the Averys. In Treasure Neverland: Real and Imaginary Pirates. Oxford: Oxford Scholarship Online. [CrossRef]

Richetti, John J. 1975. Defoe's Narratives: Situations and Structures. Oxford: Clarendon Press. 
Scotland Privy Council. 1696. Proclamation for Apprehending Henry Every, Alias Bridgeman, and Sundry Other Pirates. Edinburgh: Andrew Anderson.

Voloshinov, Valentin Nikolaevich. 1973. Marxism and the Philosophy of Language. Translated by Ladislav Matejka, and Irwin R. Titunik. Cambridge: Harvard University Press. First published 1929.

Ward, Edward. 1710. Dialogue VIII. Between King Avery, the Pirates, and his Indian Princess at Madagascar. In Nuptial Dialogues and Debates. London: printed by H. Meere, vol. 2, pp. 132-50. 